\title{
The Interaction Effect of CSR and Innovation on Firm's Performance
}

\author{
Wen-Hua Huang, Yuan-Shuh Lii \\ Feng Chia University, Taiwan; \\ E-mail address aidusu@mail.fcu.edu.tw; E-mail address yslii@ffcu.edu.tw
}

\begin{abstract}
Our CSR (corporate social responsibility) activities and innovation initiatives complementary? From a resource-based perspective, managers would develop CSR and Innovation's business strategy to create heterogeneity and build sustainable competitive advantage. Based on instrumental theories, CSR is a means for firms to accomplish economic output; therefore, CSR may lead or utilize Innovation for this purpose. As CSR is getting more attention, and Innovation is important for a firm's growth, to find the interaction effect of CSR and Innovation is getting more important. However, to our limited knowledge, there are fewer studies and discussions about the topic. Thus, the research would develop a new analysis model to study the topic. Regarding the methodology, four questions are designed to be answered, and two categories of the dataset are collected. These questions are: (1) Does CSR have an impact on firms' performance? (2) Does long-term investment have an impact on the firm's performance? (3) Does R\&D have an impact on a firm's performance? (4) How does the interaction of CSR and Innovation investment impact on firm's performance? The datasets include finical data and ESG (Environmental, Social, and Governance) ratings of firms. We would start the research from a typical industry in a country and look forward to a future extension to multiple industries across countries. We select Taiwan's electronics industry due to its important role in the global market, its leading position in Innovation, and its great efforts on CSR. So far, the research is still in progress. We would share the results, finding, and conclusion of the preliminary analysis. I look forward to your valuable comments for us to improve the analysis model and to find opportunities for further studies in other industries or other countries.
\end{abstract}

Keywords: Environmental, Social and Governance (ESG), Corporate Social Responsibility (CSR), Innovation, Innovation Investment, Firm's Performance

\section{INTRODUCTION}

This is an open access article under the CC-BY-NC license.

Referring to the data of GSIA (global sustainable investment alliance), the amount of global sustainable investment assets grows by four times in 8 years and is accumulated to 30.7 trillion dollars in 2018. In addition, the United Nations supports an initiative named PRI (the Principles of Responsible Investment) to ask investing institutions putting ESG (environmental, social, and governance) into the investment analysis and decision-making process. The initiative has invited more than 2370 investing institutions to sign in. Furthermore, there are more and more ESG related indexes for investors. One of the most famous ESG indexes is the DJSI (Dow Jones Sustainability 
Index). There are many top tiers of firms applying for these kinds of ESG index. ESG ratings as a metric of CSR activities, we would study its relation with the firm's performance.

Innovation is one of the drivers for a firm's performance. Usually, R\&D is used as an innovation investment for most firms. In the highly competitive era, internal R\&D is no longer enough, and more firms have multi-dimensional Innovation, including corporate venturing investment or external partnership. The long term investment is used as another type of innovation investment. Considering both R\&D and long-term investment as two types of innovation investment, we would study their relationship with the firm's performance.

From a resource-based perspective, both CSR activities and Innovation drive the firm's competitive advantage, but both of them also consume the firm's resources. Based on instrumental theories, CSR activities may lead to Innovation, and Innovation may benefit CSR. Managers should fully understand the interaction effect of CSR and Innovation, and then make the best decision of investment. Therefore, after we analyze the relation of ESG ratings or Innovation with a firm's performance, respectively, we would further analyze the interaction effect of ESG ratings and Innovation on the firm's information.

\section{LITERATURE REVIEW}

\section{Electronics Industry in Taiwan}

Taiwan's electronics industry plays a very critical role in the global supply chain of electronic products. The industry includes seven sub-fields: semiconductor, optoelectronic, communications \& internet, information service, computer \& peripheral equipment, electronic parts or components, and electronic product distribution. In each field, many of Taiwan's firms play key roles in technology, innovative design, or manufacturing quality. As they supply for global partners, they need to follow the global CSR expectation. The easiest method is to win the ESG recognition by listing in the global ESG index. On the other hand, they also play important roles in the local market. The means $43 \%$ of firms, $75 \%$ of trading value, and $60 \%$ of trading volume in Taiwan Stock Exchange. Both CSR activities and Innovation is necessary for maintaining its brand image, market value, and sustainability.

\section{Resource-Based Perspective and CSR}

From a resource-based perspective, CSR is seen as providing internal or external benefits or both. (Branco, \&Rodrigues, 2006) Carroll proposed CSR as a pyramid, including the economic, legal, ethical, and philanthropic concerns (Carroll, 1991). A firm's CSR actions should be in harmony with societal values and expectations (Lerner \& Fryxell,1988). CSR is a voluntary, and not legally mandatory, the response of a company that wants to protect its long-term goal (Mortreu, 2019). Firms innovate to make the resource till best utilization so as to maintain competitive advantage and performance (Lee, Liu, \&Yang, 2011). From stakeholder theories, many firms bring positive effects to their shareholders and other stakeholders by investing in CSR activities so as to meet the goal of business sustainability (Peters \& Mullen, 2009). In order to easily demonstrate their CSR performance, ESG becomes a dominant metric in the area of non-financial reporting and is top of mind for contemporary executives, because corporations will soon be held accountable by shareholders for their ESG performance (Eccles \& Klimenko, 2019). ESG scores refer to the three central factors in measuring the sustainability and ethical impact of a business (Mortreu, 2019). ESG ratings have a positive relation with a firm's performance (Lee, Liu, \&Yang, 2011). To sum up, it comes out with the first hypothesis.

Hypothesis 1: CSR (by ESG ratings) has an impact on the firm's performance. 


\section{Innovation and Firm's performance}

Innovation is considered to be one of the main drivers of corporate success in a competitive environment in the long run. Innovation investments are different from other investments because there always exists an uncertainty of the innovation outcome and its returns (Mortreu, 2019). Regarding innovation investment, people tend to use the level of R\&D expenditures as the input .. but two types of Innovation as exploitation investment (capital expenditure) and exploration investment (R\&D expenditure) (Kim, Brodhag, \&Mebratu, 2014). The venturing investment helps firms to absorb specific external new knowledge and to access the new technology and markets. The effect of venturing investment on innovation performance is significant (Gils, 2012). The firms would increase the venturing investment to innovate for growth so as to meet the historical and social aspiration, so the long-term investment over the firm's total asset is used as input of venturing investment (Chiu, Chiu, Liaw, \&Lee, 2010). So the second hypothesis is as below.

Hypothesis 2: Long-term investment has an impact on a firm's performance.

Regarding the R\&D investment, the time-lag effect should be considered, and two years at least (Wang, Wang, \&Wu, 2007). So the third hypothesis is as below.

Hypothesis 3: R\&D investment has an impact on a firm's performance.

\section{ESG ratings and Innovation}

CSR initiatives can lead to Innovation through the use of social, environmental, or sustainability drivers to create new ways of working, new products, services, processes, and new market space (Little, 2006). Sustainable development brings some considerable challenges to businesses that emphasize the directions that innovation activities can take. And the existing processes and tools for Innovation are suggested to increase CSR adoption, through, e.g., ecoinnovation (Rexhepia, Kurtishib, \&Bexhetic, 2013). The results that CSR activities have a positive effect on Innovation (Kim, Brodhag, \&Mebratu, 2014). ESG ratings have a positive effect on Innovation (Lee, Liu, \&Yang, 2011). CSR and Innovation are complementary. (Mortreu, 2019). So the fourth hypothesis is as below.

Hypothesis 4: The interaction effect of CSR (by ESG ratings) with long-term investment or $R \& D$ investment on the firm's performance is significant.

\section{RESEARCH METHODOLOGY}

\section{Research design}

The analysis model includes two stages. In the first stage, we analyze the relation of a firm's performance with ESG ratings, Long-term investment, and R\&D investment, respectively. We use three equations to do the regression. In each equation, the dependent variable is firm's performance (symbol: FP), the independent variables are ESG ratings (ESG), longterm investment (LTInv) and $\mathrm{R} \& \mathrm{D}$ expenditures in three years (RDC, RDP, RDe), and the control variables (CVs) are total asset effect (TAe), market value (Tobin), and debt ratio (DAR).

Equation 1: $F P=f(x), x=E S G, C V S$

Equation 2: $F P=f(x), x=$ LTInv, CVS

Equation 3: $F P=f(x), x=R D c, R D p, R D e, C V s$

In the second stage, we analyze the interaction effect of ESG ratings with Long-term investment as well as R\&D investment. The dependent variable and control variables are the same as above.

Equation 4: $F P=f(x), x=E S G, L T I n v, R D c, R D p, R D e, E S G^{*}(L T I n v, R D c, R D p, R D e), C V S$ 


\section{Description and Statistics of Variables}

Table 1 demonstrates the description and basic statistics. The mean of firms' performance, EBITDA rate, is $10 \%$. The mean of ESG ratings is 2.389. The mean of a longterm investment divided by total assets is $47.2 \%$. The mean of R\&D expenditure divided by sales is around $7.5 \%$.

Tabel 1. Description and Statistics of Variables

\begin{tabular}{lllll}
\hline Variables & Description & Observation & Mean & Standard Deviation \\
\hline FP & Firm's performance, EBITDA/Sales $^{\text {a }}$ & 976 & 0.100 & 0.524 \\
\hline ESG & ESG ratings $^{\mathrm{b}}$ & 976 & 2.389 & 0.914 \\
\hline LTInv & Longterm investment/Total Asset $^{\prime}$ & 976 & 0.472 & 5.139 \\
\hline RDc & Current year's R\&D expense/Sales & 976 & 0.075 & 0.124 \\
\hline RDp & Previous year's R\&D expense/Sales & 976 & 0.073 & 0.131 \\
\hline RDe & Earlier year's R\&D expense/Sales & 976 & 0.073 & 0.143 \\
\hline TAe & Total Asset effect: Total Asset/Sales & 976 & 1.851 & 5.356 \\
\hline TobinQ & Tobin's Q & 976 & 1.235 & 1.024 \\
\hline DAR & Debt Asset Ratio: Debt/Total Asset & 976 & 0.430 & 0.018 \\
\hline
\end{tabular}

${ }^{\mathrm{a}}$ EBITDA means Earning before interest, tax, depreciation and amortization. ${ }^{\mathrm{B}}$ The distribution of ESG ratings by counts: 5 counts (38 observations), 4 counts( 82 observations), 3 counts(197 observations), 2 counts( 564 observations), 1 (95 observations)

\section{Data Collection}

The research collects the data from two categories: financial information and ESG ratings information. First, we collect firms' specific financial information from TEJ (Taiwan Economic Journal). We select the category of the Electronics Industry in Taiwan Stock Exchange. The data period is from 2017 to 2019. Secondly, we collect ESG ratings information from official websites of related rating institutions, such as Taiwan Stock Exchange Corporation, CommonWealth Magazine, and DJSI website.

\section{Data Cleaning and Analysis}

There are 1225 observed items from 409 listed firms of the specific industry in the Taiwan Stock Exchange. We remove those firms without complete financial data, especially R\&D expenditure, long-term investment, or EBITDA data. After cleaning, we finally use the left 976 observations for analysis. Our empirical analysis is a robust regression to find the correlation between the FP and related independent variables and control variables. Ordinary Least Squares regression is applied for the analysis.

\section{FINDING AND DISCUSSION}

\section{Results and Finding}

Table 2 demonstrates the results of three regression equations. For all of these three equations, the general R-squares (coefficient of determination) are around 0.7, which means there is a high degree of the model explanation. The ANOVA F-test results support the results too.

For equation one supports that ESG ratings have a positive impact on a firm's performance. Is positive. 
Equation 2 supports that long-term investment has a negative impact on a firm's performance. It may be debriefed as that some firms' useless longterm investment becomes firms' burden.

For equation 3, it supports that the current year's and the previous year's R\&D expenditure has a positive relationship with the firm's performance, but the earlier year's $R \& D$ has a negative relation.

Regarding the control variables, the total asset effect (total asset over sales) has a negative effect on the firm's performance, and the market value (Tobin's Q) has a positive effect on the firm's performance. However, the debt ratio (debt over total asset) has no significant effect on the firm's performance.

Tabel 2. Results of Equation 1 to 3

\begin{tabular}{llll}
\hline \multicolumn{4}{c}{ Tabel 2. Results of Equation 1 to 3 } \\
\hline Variables & Equation 1: ESG & Equation 2: LTInv & Equation 3: RD \\
\hline LTInv & $0.040^{* * *}$ & \\
\hline RDc & & $-0.034^{* * *}$ \\
\hline RDp & & $1.086^{* *}$ \\
\hline RDe & $-0.081^{* * *}$ & $-0.057^{* * *}$ & $2.091^{* *}$ \\
\hline TAe & $0.026^{* * *}$ & $0.031^{* * *}$ & $-3.355^{* * *}$ \\
\hline TobinQ & 0.000 & 0.000 & $-0.066^{* * *}$ \\
\hline DAR & 976 & 976 & $0.022^{* *}$ \\
\hline Observation & 0.694 & 0.733 & 0.000 \\
\hline R-square & 0.693 & 0.732 & 976 \\
\hline Adjusted R-square & 651.134 & $0.000^{* * *}$ & 0.708 \\
\hline ANOVA F value & 552 & 0.707 \\
\hline ANOVA p-value & $0.000^{* * *}$ & & 392.260 \\
\hline
\end{tabular}

$* p<0.1, * * p<0.05, * * * p<0.01$

Table 3 demonstrates the correlation coefficients of these variables. It is interesting that the coefficient of ESG ratings and any kind of investment (long-term investment, R\&D expenditure) is negative. But the coefficient of R\&D expenditure and long-term investment is positive.

Tabel 3.The correlation coefficient of variables

\begin{tabular}{|c|c|c|c|c|c|c|c|c|c|c|c|c|c|}
\hline Variables & FP & ESG & LTIn & RDc & RDp & RDe & $\begin{array}{l}\text { ESG* } \\
\text { LTIn }\end{array}$ & $\begin{array}{l}\text { ESG* } \\
\text { RDc }\end{array}$ & $\begin{array}{l}\text { ESG* } \\
\text { RDp }\end{array}$ & $\begin{array}{l}\text { ESG* } \\
\text { RDe }\end{array}$ & TAe & $\begin{array}{l}\text { Tobin } \\
\text { Q }\end{array}$ & $\begin{array}{l}\text { DA } \\
\mathbf{R}\end{array}$ \\
\hline FP & 1 & & & & & & & & & & & & \\
\hline ESG & 0.161 & 1 & & & & & & & & & & & \\
\hline LTInv & -0.77 & -0.074 & 1 & & & & & & & & & & \\
\hline RDc & -0.602 & -0.111 & 0.508 & 1 & & & & & & & & & \\
\hline
\end{tabular}


Proceeding on Japan International Business and Management Research Conference (JIBM),

Vol. 1(1), 1-8

The Interaction Effect of CSR and Innovation on Firm's Performance

Wen-Hua Huang, Yuan-Shuh Lii

\begin{tabular}{lccccccccccccc}
\hline RDp & -0.647 & -0.121 & 0.554 & 0.987 & 1 & & & & & & & \\
\hline RDe & -0.696 & -0.13 & 0.602 & 0.966 & 0.989 & 1 & & & & & & \\
\hline ESG*LTIn & -0.893 & -0.049 & 0.857 & 0.580 & 0.634 & 0.690 & 1 & & & & & \\
$\mathrm{v}$ & & & & & & & & & & & & \\
\hline ESG*RDc & -0.309 & 0.173 & 0.277 & 0.867 & 0.832 & 0.783 & 0.313 & 1 & & & & \\
\hline ESG*RDp & -0.715 & -0.047 & 0.627 & 0.888 & 0.893 & 0.886 & 0.726 & 0.731 & 1 & & & \\
\hline ESG*RDe & -0.873 & -0.058 & 0.806 & 0.754 & 0.787 & 0.819 & 0.939 & 0.507 & 0.914 & 1 & & \\
\hline TAe & -0.829 & -0.109 & 0.769 & 0.732 & 0.771 & 0.811 & 0.897 & 0.467 & 0.850 & 0.943 & 1 & \\
\hline TobinQ & 0.029 & 0.022 & 0.042 & 0.146 & 0.127 & 0.108 & 0.060 & 0.175 & 0.055 & 0.050 & 0.029 & 1 \\
\hline DAR & 0.057 & 0.063 & -0.032 & -0.064 & -0.065 & -0.064 & -0.045 & -0.024 & -0.063 & -0.059 & -0.062 & -0.023 & 1 \\
\hline
\end{tabular}

Table 4 demonstrates the results of equation 4 . The general R-square of the equation is 0.838 , which means the higher model explanation level. The ANOVA F-test supports it too.

Tabel 4. Interaction effect of ESG and Innovation investment (Equation 4)

\begin{tabular}{llll}
\hline Variables & Coefficient & P-value & Significant \\
\hline ESG & 0.028 & 0.008 & Significant \\
\hline LTInv & 0.000 & 0.936 & Significant \\
\hline RDc & -1.572 & 0.001 & \\
\hline RDp & 1.209 & 0.075 & Significant \\
\hline RDe & -1.035 & 0.015 & Significant \\
\hline ESG*LTInv & -0.009 & 0.002 & Significant \\
\hline ESG*RDc & 0.577 & 0.000 & Significant \\
\hline ESG*RDp & -0.377 & 0.524 & Significant \\
\hline ESG*RDe & 0.070 & 0.862 & \\
\hline TAe & 0.017 & 0.000 & 0.000 \\
\hline TobinQ & 0.043 & 0.723 & \\
\hline DAR & 0.000 & $F v a h e$ & \\
\hline
\end{tabular}

${ }^{a} R$ square is 0.838 ; the adjusted $R$ square is 0.836 . ANOVA F value is 414.764 , p-value is $0.000^{* * *}$

Regarding longer investment, it has a negative relation with the firm's performance alone. After interaction with ESG ratings, itself becomes not-significant, and the interactive effect is negative too.

Regarding the current year's R\&D expenditure, it has a positive relationship with the firm's performance alone. After interaction with ESG ratings, itself becomes negative, and the interactive effect is positive. 
Regarding the previous and earlier R\&D expenditure, they have a positive and negative relationship with the firm's performance alone. But there are no significant interaction effects with ESG ratings.

\section{Discussion}

We may interpret the interaction effects of the stakeholder theory. As CSR initiatives play an important role in serving stakeholders' needs and to achieve corporate sustainability, firms may use CSR to lead Innovation or improve the efficiency of investment. When R\&D or long-term investment is reviewed separately, some investment just brings negative effects alone. However, when R\&D or long-term investment is put with CSR together, CSR eliminates the negative effects of R\&D or a long-term investment. In other words, CSR generates the interaction effects with the investment. From resource-based perspectives, firms need to allocate resources to create competence for competitive advantages. So firm managers may consider CSR as an innovation driver to make optimal resource allocation on $\mathrm{R} \& \mathrm{D}$ or a long-term investment.

\section{CONCLUSION AND FURTHER RESEARCH}

There are four questions we address in the beginning: (1) Does CSR have an impact on firms' performance? (2) Does long-term investment have an impact on a firm's performance? (3) Does R\&D have an impact on a firm's performance? (4) How does the interaction of CSR and investment impact a firm's performance? After the analysis, the results are (1) Yes, positive. (2) Yes, negative. (3) Yes, positive (current year), positive (previous year), and negative (earlier year), respectively, and (4) CSR generates interaction effect with long-term investment to eliminate the impact, and CSR also generates interaction effect with $R \& D$ investment on firm's performance. To sum up, the finding suggests that firm managers may consider CSR as an innovation driver to make optimal resource allocation on $\mathrm{R} \& \mathrm{D}$ or a long-term investment.

Regarding the contribution of the research, it is not only on the findings described above but also on the analysis model. We adopt ESG ratings as the metric of CSR, we take two types of innovation investment, and we consider the interaction effects of CSR with investment. This model is an innovation itself and deserves further modification.

Regarding the limitation, we think the data of ESG ratings is a limitation now, and crossindustries or cross-countries study is a challenge. So we start with Taiwan's electronics industry and collect the limited.

\section{REFERENCES}

Branco, M.C., Rodrigues, L. (2006). Corporate social responsibility and resource-sased perspectives, Journal of Business Ethics, 69(2) 111-132.

Carroll, A.B. (1991). The pyramid of corporate social responsibility: Toward the moral management of organizational stakeholders. Business Horizons, 34: 39-48.

Chiu, Y.C., Chiu, S.K., Liaw, Y.C., Lee, T.Y. (2010). The Antecedents corporate venturing investment, Intelligence Property Review, 8(1),117-144.

Eccles, R.G., Klimenko, S. (2019). The Investor Revolution, 108-116.

Gils, M., (2012). Analyzing the effect of corporate venture capital investments on a corporation's innovative performance, Tilburg School of Economics and Management.

Kim, Y., Brodhag, C., Mebratu, D, (2014). Corporate social responsibility drove Innovation, Innovation: The European Journal of Social Science Research, 27(2) 175-196.

Lerner, D.L., Fryxell, E.G. (1988). An empirical study of the predictors of corporate social performance: a multi-dimensional analysis. Journal of Business Ethics 7: 951-959. 
Little, A. (2006). The Innovation high ground: Winning tomorrow's customers using sustainabilitydriven Innovation. Strategic Direction, 22(1), 35-37.

Mortreu, V. (2019). The complementarity of corporate sustainability and Innovation: evidence from the Pharmaceutical Industry, Digital access to Libraries, Louvain School of Management.

Rexhepia, G., Kurtishib, S., Bexheti, G. (2013). Corporate social responsibility (CSR) and Innovation -The drivers of business growth? Procedia - Social and Behavioral Sciences, 75 (2013) 532 541.

Wang, HW., Wang, T., Wu, MC.,(2008). Business types and R\&D activities performance, Journal of Management, 25(2), 173-193. 